\title{
Effectiveness of Computer-Based Learning Media with Interactive-Tutorial Model for Medical Physics Subject
}

\author{
Junios $^{\mathrm{a}, 1}$, D. Kariman ${ }^{\text {b,2 }}$, R. Wulan ${ }^{\mathrm{c}}$, Yulkiflic \\ ${ }^{a}$ STIKes Ceria Buana Lubukbasung, Jl. Tuanku Nan Renceh Lubukbasung, Kabupaten Agam, Sumatera Barat, Indonesia \\ ${ }^{\mathrm{b}}$ STKIP PGRI Sumatera Barat, Padang, Sumatera Barat, Indonesia \\ ${ }^{\mathrm{c}}$ Universitas Negeri Padang, Jl. Prof. Hamka, Padang, Sumatera Barat, Indonesia \\ juniosssi@yahoo.co.id, ${ }^{2}$ delsikariman79@gmail.com
}

\begin{abstract}
This paper discusses validity, practicality and effectiveness of computer-based learning media with interactivetutorial model for medical physics subject in West Sumatera. The prototype was validated by six validators of learning media, language, and medical physics learning. Based on their suggestions, the prototype was revised. After revised, the prototype was tested to detemine practicality and effectiveness of the learning media. Questionnaires on practicality of learning media were filled by medical physics lecturers and students. The effectiveness of learning media was obtained from test sheets. It was obtained that: 1) computer-based learning media with interactive-tutorial model is valid in terms of the aspects of didactic, construction, and technique; 2) computer-based learning media with interactive-tutorial model is practical in terms of the aspects of time, usage, and equipment of learning media component; 3 ) computer-based learning media is effective.
\end{abstract}

Index Terms - interactive learning media, medical physics, computer-based learning.

\section{Introduction}

Vision of STIKes Ceria Buana, which is developing academy and professional education and centre of science, is to yield competence-based graduates. Based on this vision, STIKes Ceria Buana has several missions including holding education of qualified medical staff according to market demands and globalization era, creating conducive academic climate, developing research activity in health domain to support learning process, holding a dedication to society as science application in health domain to increase society health degree, and preparing students who can integrate, participate and contribute in the development and progress of family, environment, society and country.

One of solutions that can be done to reach those missions is developing learning media to increase students' competences. It was found that students' understanding on medical physics subject is low as shown by many STIKes Ceria Buana students who took the subject for second time. This condition can bother the students' eduation process.

Based on Table 1, it can be seen that the students who took medical physics subject for the second time is high, that is more than $37.5 \%$. This reality is more serious because this subject is a basic subject for physiology and biochemical subjects. Low students' understanding is caused by more materials delivered and less time allocated for this subject. Another cause is low students' academic ability so that the students cannot learn independently. Therefore, the students must get guidances from their lecturers.

Table 1 Recapitulation of the students who took medical physics for the second time in STIKes Ceria Buana

\begin{tabular}{ccccccc}
\hline $\begin{array}{c}\text { Learning } \\
\text { Year }\end{array}$ & \multicolumn{5}{c}{ The students who took the subject for the second time } \\
\cline { 2 - 8 } & $\begin{array}{c}\text { Medical } \\
\text { Physics A }\end{array}$ & $\begin{array}{c}\text { Number of } \\
\text { Students }\end{array}$ & $\%$ & $\begin{array}{c}\text { Medical } \\
\text { Physics B }\end{array}$ & $\begin{array}{c}\text { Number of } \\
\text { Students }\end{array}$ & \% \\
\hline $2009 / 2010$ & 18 & 48 & 37.5 & 45 & 120 & 37.5 \\
\hline $2010 / 2011$ & 17 & 45 & 37.7 & 47 & 110 & 42.7 \\
\hline $2011 / 2012$ & 17 & 37 & 45.9 & 40 & 89 & 44.9 \\
\hline
\end{tabular}

A possible solution for the problem is making learning media integrated with communication and technology. Based on the advancement of communication and technology in campus, the usage of learning media could increase the effectiveness of learning. We hope that learning media could also stimulate students' motivation in learning medical physics so that the the problem could be overcome.

\section{Learning Media with Interactive-Tutorial Model for Medical Physics}

\subsection{The essence of Medical Physics learning}

According to behavioristic theory, learning is making association between impression that be caught by sensory perception and trend to do, or relation between stimulus and response. Learning is an effort to form many relations between stimulus and response. The relation between stimulus and response will be formed by using learning media, because learning media can stimulate sensory perception simultaneously.

The essence of learning is making students to learn. The student environment is created to stimulate students' motivation to learn. This motivation will appear if students are interested in given materials of subject. One solution to make students interested in is using learning media. In addition, students must learn independently in classrooms and outside classrooms. The competence-based curriculum in STIKes Ceria Buana can guide students to learn independently without direct guidance of lecturers. Therefore, lecturers must make interactive learning media so that students do not depend on direct learning in classrooms.

Learning indepedently is a way of active learning to develop student who is so independent that the student does 
not depend on lecturers' attendance, meeting in classroom, friends' attendance in classroom. Learning independently needs motivation, seriousness, discipline, responsibility, and curiosity.

Medical physics is the basic of development of modern health science and technology. At present, the development of medical physics helps healing cancer patient without operation and radiotherapy as healing prostate cancer patient, breast cancer, cervical cancer, etc. Moreover, in medical physics, there are materials on biomechanics, which is the basic of motion on the human body.

\subsection{Computer-Based Learning Media}

Media are understood as humans, materials, or events that make humans get knowledge, skill or attitude. It means that lecturers, textbooks, and school environment are media. Media are all of intermediate forms that are used by humans in delivering or spreading idea or opinion. Furthermore, media is learning source that can stimulate students to study.

The term of media used in education world is learning media. Learning media consist of book, tape recorder, video camera, video recorder, film, slide, photo, picture, graph, television, and computer. Learning media can also be hardware and software. Hardware is tools that can deliver message, like overhead projector (OHP), radio, television, and so on. Software is programs that contain messages, like information on book or other printed materials, the story in film, or material in chart, graphs, diagram, and so on.

\subsection{Learning Outcomes}

In learning process, behavior changes in cognitive, affective, or psychomotor aspects could occur. These changes are the effect of activities or exercises that students did during learning process. They are called as learning outcomes.

\section{Methodology of Research}

\subsection{Types of Research}

This research is development research collaborated with pre-experiment using one-shoot case study design.

\subsection{Procedure}

This development research used Plomp model, which consists of five phases: (a) preliminary investigation, (b) design, (c) realization, (d) test, evaluation, revision, and (e) implementation.

\subsubsection{Preliminary Investigation Phase}

Activities that have been done in the preliminary investigation phase were lecturing contract analysis, material analysis, review of literature, interviewing of medical physics lecturer, and interviewing of students.

\subsubsection{Design Phase}

The result of preliminary investigation was used to design the desired computer-based learning media with interactive-tutorial model. In this phase, structures of program and storyboard were designed. The structure of program consisted of introduction, instruction of lecturing, material, main menu, and evaluation. Based on the structure of program, storyboard as the description of each scene was designed. The result of storyboard was used to make each scene on computer-based learning media with interactivetutorial model.

\subsubsection{Realization Phase}

Design of storyboard was used in the realization phase. The realization phase involves collecting needed objects, such as texts, pictures, and sounds. Collecting objects was done by using Adobe Flash Profesional cs6 ste.

\subsubsection{Test, Evaluation, and Revision Phase}

There were two main activities in this phase that is validation and testing of prototype. The validation of prototype consisted of validation of content and construct. The prototype and questionnaires of validity were given to six validators of learning media, language, and medical physics learning. The prototype was then revised. After revised, the prototype was tested to medical physics lecturers and STIKes students. There were two tests: limited test and field test. The limited test was given to medical physics lecturers and STIKes Ceria Buana students who ever studied the medical physics subject. The lecturers and students were then given questionnaires of practicality of computer-based learning media with interactive-tutorial model. Revision was done after the results of questionnaires of practicality of the learning media were obtained.

After limied test and revision were done, the field test was given to STIKes students in West Sumatera. The preexperiment research was also done in this phase using one shoot case study design. The given treatment was learning using computer-based learning media with interactivetutorial model for the medical physics subject. Based on the tests results it was seen the effect of treatment on learning outcomes.

\subsubsection{Implementation Phase}

The aim of field test was to conclude whether computer-based learning media with interactive-tutorial model is effective or not. If the results indicated that the learning media with interactive-tutorial model is effective, then it will be implemented in medical physics learning.

\subsection{Instruments Used}

Instruments used in this research were questionnaires of validity, questionnaires of practicality, and test sheets. The questionnaires of validity and practicality were made using Likert scale. These questionnaires were used to conclude whether the computer-based learning media with interactive-tutorial model are valid and practical or not. The test sheets were used to conclude whether the computerbased learning media with interactive-tutorial model was effective or not.

\section{Results and Discussion}

The results of this research were the medical physics learning media including theory, simulation, video, exercises, and evaluation stored a compact disk (CD). Screenshots of the learning media is shown in Fig. 1. 

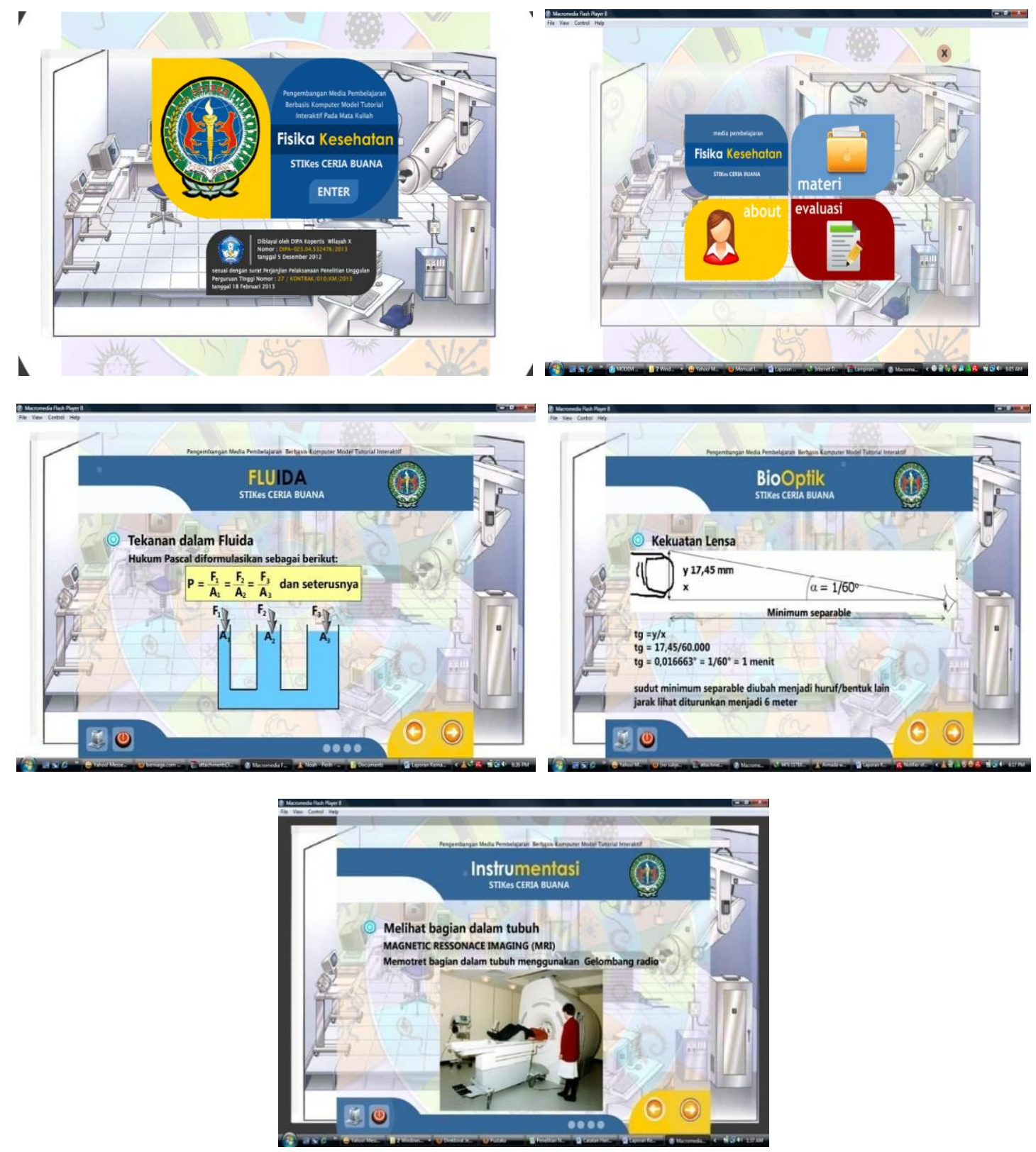

Fig. 1 The screenshots of the learning media.

Table 2 Practicality of computer-based learning media with interactivetutorial model based on medical physics lecturers' assestment

\begin{tabular}{clcc}
\hline No & \multicolumn{1}{c}{ Aspect evaluated } & Scores (\%) & Category \\
\hline 1 & The timeliness & 79.17 & Practical \\
\hline 2 & $\begin{array}{l}\text { Ease of use of computer- } \\
\text { based learning media } \\
\text { interactive-tutorial model }\end{array}$ & 87.50 & $\begin{array}{c}\text { Very } \\
\text { practical }\end{array}$ \\
\hline 3 & $\begin{array}{l}\text { Completeness of component } \\
\text { of computer-based learning } \\
\text { media interactive-tutorial } \\
\text { model }\end{array}$ & 89.26 & $\begin{array}{c}\text { Very } \\
\text { practical }\end{array}$ \\
\hline
\end{tabular}

From the questionnaires given to either the medical physics lecturers or the students, it was obtained that the computer-based learning media with interactive-tutorial model is valid for the aspects of didactic, construction, and technique. The limited test results indicated that the prototype of computer-based learning media with interactive-tutorial model is practical and satisfied as tabulated in Tables 2 and 3.

Table 3 Practicality of computer-based learning media with interactive tutorial model based on students' assestment

\begin{tabular}{clcc}
\hline No & \multicolumn{1}{c}{ Aspect evaluated } & Scores (\%) & Category \\
\hline 1 & The timeliness & 77.08 & Practical \\
\hline 2 & $\begin{array}{l}\text { Ease of use of computer- } \\
\text { based learning media with } \\
\text { interactive-tutorial model }\end{array}$ & 81.39 & $\begin{array}{c}\text { Very } \\
\text { practical }\end{array}$ \\
\hline 3 & Usage hoped by students & 78.89 & Practical \\
\hline
\end{tabular}


Moreover, Table 3 suggests that the learning media can help students learn independently, understand concept, and improve the ability of problem solving in medical physics subject.

After using the learning media CD, the students were tested for their abilities in concept understanding, scientific reasoning, and problem solving. The test results showed that their achievements were very good as given in Table 4 .

Table 4 Percentage of students' achievement

\begin{tabular}{clc}
\hline No & \multicolumn{1}{c}{ Cognitive ability } & Percentage (\%) \\
\hline 1 & Concept understanding & 77.08 \\
\hline 2 & Scientific reasoning & 81.39 \\
\hline 3 & Problem solving & 78.89 \\
\hline
\end{tabular}

\section{Conclusion}

Computer-based learning media with interactive-tutorial model for Medical Physics have been developed. From the lecturers' and students' points of view, the learning media is overall good in terms of validity, practicality, and effectiveness.

\section{Acknowledgment}

We would like to thanks "Kementerian Pendidikan dan Kebudayaan (Kemendikbud) RI" for financial support of this work through project "Penelitian Kerjasama Perguruan
Tinggi"
(PEKERTI)
with
contract
number

18/KONTRAK/010/KM/2014.

\section{References}

[1] Junios, D. Kariman, R. Wulan, and Yulkifli, "Pengembangan media pembelajaran berbasis komputer model tutorial interaktif pada mata kuliah Fisika Kesehatan Mahasiswa STIKes di Sumatera Barat", Prosiding Seminar Nasional Fisika IV 2013, Semarang, 12 Oktober 2013, pp. FP-127-FP-132.

[2] R. E. Mayer, Multimedia Learning, Second edition. New York: Cambridge University Press, 2009.

[3] T. Plompt and N. Nieveen N, An Introduction to Educational Design, Netherlands Institute for Curriculum Development, 2010. 